\title{
FAMILY SUPPORT FOR PSYCHOLOGICAL HEALTH OF THE ELDERLY
}

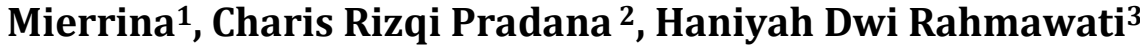 \\ 1,2,3Sunan Ampel State Islamic University, Surabaya \\ mierrina@uinsby.ac.id; charis.rizqi.pradana.s.sos.i.m.pd@dlb.uinsby.ac.id; \\ haniyahdwira31@gmail.com
}

\begin{abstract}
With the increasing number of elderly people, of course, there will be more and more complex problems that must be faced by these elderly people. Elderly people are no longer independent or dependent on others, unable to carry out activities on their own, need caregivers, have cognitive and functional decline, have complex psychosocial problems, and have multiple diseases. This study aims to provide an overview of the form of support and its impact on the health of the elderly by providing an overview through literature review research. Research data was obtained through literature study and hermeneutics. Family support can provide great hope for elderly people to continue to instill many positive things and reduce the negative possibilities experienced by them. Ways to provide support to the elderly can be: taking family members for walks, hanging out with friends, being with them throughout the day, and respecting one another. The benefits of providing the above are that there is an increasingly close family relationship, trusted by elderly parents, to be asked for any help, not awkward in expressing any opinion. This has an impact on the emotional stability of the elderly in living their lives.
\end{abstract}

Keywords: Family Support, Psychological Healthy, Elderly

\begin{abstract}
Abstrak: Dengan semakin banyaknya orang lanjut usia, maka tentunya akan semakin banyak dan kompleks pula permasalahan yang harus dihadapi oleh orang lanjut usia ini. Orang lanjut usia sudah lagi tak mandiri atau bergantung dengan orang lain, tidak bisa melakukan aktivitas sendiri, membutuhkan pengasuh, kognisi dan fungsional yang menurun, masalah psikososial yang kompleks, dan memiliki multipel penyakit. Penelitian ini bertujuan untuk memberikan gambaran mengenai bentuk dukungan serta dampaknya bagi kesehatan orang lanjut usia dengan memberikan gambaran melalui penelitian literatur review. Data penelitian diperoleh melalui studi kepustakaan dan hermeneutika. Dukungan keluarga dapat memberikan harapan besar bagi orang lanjut usia untuk terus menanamkan banyak hal positif dan mengurangi kemungkinan negatifyang dialami oleh mereka. Cara untuk memberikan dukungan kepada orang lanjut usia dapat berupa : mengajak jalan-jalan bersama anggota keluarga, berkumpul bersama teman-teman, menemani sepanjang hari dan menghargai satu sama lain. Manfaat dari memberikan hal diatas yaitu adanya hubungan keluarga yang semakin rekat, dipercaya oleh orangtua berusia lanjut, untuk diminta bantuan apapun, tidak canggung dalam mengutarakan pendapat apapun. Hal itu berdampak pada stabilitas emosi orang lanjut usia dalam menjalani kehidupannya.
\end{abstract}

Kata Kunci: Dukungan Keluarga, Kesehatan Psikologis, Orang Lanjut Usia

\section{A. Introduction}

Based on Law Number 13 of 1998 concerning the Welfare of the Elderly, an elderly person is someone who reaches the age of 60 years and over. Currently, Indonesia is entering a period of an aging population, where there is an increase in life expectancy followed by an increase in the 
number of elderly people. Indonesia experienced an increase in the number of elderly people from 18 million people $(7.56 \%)$ in 2010 , to 25.9 million people $(9.7 \%)$ in 2019 , and is expected to continue to increase wherein 2035 to 48.2 million people $(15,77 \%){ }^{1}$

With the increasing number of elderly people, of course, there will be more and more complex problems that must be faced by these elderly people. Elderly people are no longer independent or dependent on others, unable to carry out activities on their own, need caregivers, have cognitive and functional decline, have complex psychosocial problems, and have multiple diseases. In addition, there is also violence against parents or elderly abuse. Like parents who are not cared for or neglected. 2

Naturally, humans will grow and develop, over time, when humans reach old age, the body will experience aging which is marked by changes in physical form and body functions that begin to decline. Along with increasing age, some psychological problems will appear in elderly people. Older people experience increased clinical susceptibility, among them addiction and/or death when exposed to stressors. Elderly people who are easily sick with only mild stressors, the pain can be severe and the risk of death. Vulnerability/frailty is a process that is in line with the decline in the body's functional capacity in the aging process. ${ }^{3}$

Over time, it is predicted that the number of elderly people with mental and behavioral health problems will almost quadruple, from 4 million in 1970 to 15 million in 2030. Mental health disorders, including anxiety and depression, will affect physical and psychological functioning and health These include caring for a partner with dementia or physical disability, grieving the death of a loved one, and problems managing conflict with family members. ${ }^{4}$

If a person cannot achieve integrity, then he will experience despair. He felt useless in his life, complained a lot so that the rest of his life felt very heavy. He is not able to enjoy his old age, demands a lot, whatever is felt is not right so that people around him do not know what to do to please him. For those who are still rich, their children and grandchildren may still be willing to fulfill and pay attention to it because of other expectations. However, for those who depend on their children and grandchildren, this difficulty will cause tension on both sides. This situation causes psychological health. ${ }^{5}$

Judging from the description above, the family has an important role in the psychological health of the elderly, especially family support for the elderly. Positive family support, it will help the elderly to face every problem that exists. Symptoms of depression decreased significantly in elderly people with strong family and partner support $(\mathrm{p}<0.05)$. Pain decreases as support levels increase. ${ }^{6} 56 \%$ of families can carry out maintenance of the elderly well, which affects $73 \%$ of the elderly can carry out adaptive coping mechanisms and there is a significant relationship between family tasks in health care and elderly coping mechanisms. ${ }^{7}$ There is a positive correlation between family support and the meaning of life. ${ }^{8}$

\footnotetext{
1 "Kementerian Kesehatan", Indonesia Enters the Period of Aging Population. Last modified July 04, 2019, https://www.kemkes.go.id/article/view/19070500004/indonesia-entered-period-aging-population.html 2 "CNN Indonesia Team", Challenges Facing Elderly in Indonesia, last modified September 24, 2019, https://www.cnnindonesia.com/gaya-Life/20190709091033-255-410379/tantangan-yang-dihadapilansia-di-indonesia.

3 "Kementerian Kesehatan", Keep the Elderly Healthy During the Covid-19 Pandemic, last modified June 25, 2021, https://promkes.kemkes.go.id/tetap-sehatkan-lansia-di-masa-pandemi-covid-19.

${ }^{4}$ Psychology of Aging. American Psychological Association.

${ }^{5}$ Johana E. Prawitasari. "Socio-Psychological Aspects of the Elderly in Indonesia" Bulletin of Psychology Volume 1, No: 1 (1994): 27-34.

${ }^{6}$ Man Hung et al. "The Relationship Between Family Support; Pain and Depression in Elderly With Arthritis" Psychology, Health \& Medicine Volume 22 (2017).

${ }^{7}$ Agnesia Priska L Kelen et al. "The Duties of Families in Health Care With Elderly Coping Mechanisms" Scientific Health Sciences Vol 4, No 1 (2016).

${ }^{8}$ Keren Cohen-Louck and Yael Aviad-Wilchek. "Family Support, and Social Engagement of the Elderly Residing in the Community and in Institutional Settings. Isr J Psychiatry" Suicidal Tendencies, Meaning in Life Vol. 57, No 1 (2020).
} 
Thus, family support is an important factor for the well-being and psychological health of the elderly, allowing them to be able to live their old life happily and not give up hopelessness. But in reality, family support is still a problem felt by elderly people, $55 \%$ of elderly people experience problems interacting with their families, including feeling that their family does not respect them and does not get family support. ${ }^{9}$ Timely preventive and therapeutic psychological health care for the elderly is very important.

\section{B. Theoretical Review}

\section{Family Support}

The survey found that that maintaining relationships with family and friends is more important than having financial support. Aside from older adults' views, studies have shown a direct connection between an older adult's health and their relationship with family. Indeed, family is important for the elderly's mental, physical, and social health. There are the Benefits of a Family Support System for the Elderly: ${ }^{10}$

a. Longer Life Expectancy. When older adults maintain social connections with their family members, this can increase their life expectancy compared to those that are socially isolated. It may not be an obvious benefit, but a family's presence can improve their overall health in their remaining years.

b. Stronger Immune System. Older adults that have a family support system and regularly connect with others typically have stronger immune systems. This is a major benefit, especially since older adults tend to have weaker immune systems as they age. In turn, a healthier immune system will be better equipped to fight off illnesses that older adults come in contact with.

c. Better Mental Health. Another benefit for seniors that stay close with family is having improved mental health compared to those that aren't close to loved ones. It's important for older adults to socialize with their family and to be reminded that they are loved and valued. This can help seniors be less likely to suffer from mental illnesses like depression.

d. Better Brain Health. Older adults who stay socially connected also benefit from having higher levels of cognitive function. Studies have shown that those that enjoyed participating in social activities were more likely to have better memory and thinking skills. On the other hand, older adults that did not enjoy socializing experienced a decrease in their cognitive health.

e. A Family Support System. Like any family, the type of support and interactions change overtime. A parent that once supported and took care of their child will eventually have the roles reversed as the adult child cares for and supports the aging parent. This is a normal part of life. For many aging parents, financial support is necessary to receive the medical care required as they age. When their family is able to offer this support, this can melt away some of the stress that an older adult may feel. This is important, especially when stress can weaken an older adult's already weakened immune system. Additionally, emotional support is another major benefit of having a support system. It helps to have someone to talk to and listen to them about their good and bad days. This shows them that their family cares, which can have a positive impact on their outlook on life. Another type of support is to help older adults perform daily activities, such as cleaning their house, going shopping, or even cooking. If an older adult has a bigger family, the family can take turns helping the older adult out. These simple acts can make a big difference in helping seniors not feel alone.

f. Friendships Are Important Too. Since not every older adult has family near them, they can still benefit from social connections and support from old and new friends. Studies have shown that having strong social connections has a positive benefit to seniors' health, whether that is with

\footnotetext{
9 Mierrina, and Pradana Charis Rizki. "Psychological Health Of Elderly People In The Covid-19 Pandemic". International Conference on Sustainable Health Promotion 2, no. 1 (October 6, 2021): 44-47. http://proceedings.uinsby.ac.id/index.php/ICOSHPRO/article/view/474

10 "Liberty Home Care", Why a Family Support System is Important for The Elderly. https://libertyhomecare.com/why-a-family-support-system-is-important-for-the-elderly/
} 
friends or family. If an older adult wants to make new friends, there are quite a few tips to achieve this great goal. Older adults can visit their local pool, volunteer at a local organization, take a community class for seniors, or join a gym. There are plenty of options to discover new friendships and stay connected with others.

\section{Elderly People and Psychological Health}

Old age is the final stage of development in the human life cycle and is characterized by a person's failure to maintain a balance of health and physiological stress conditions. Old age is also associated with decreased ability to live and individual sensitivity. According to the World Health Organization (WHO), the elderly age limits include:

1. 1. Middle age, is the age group of 45 to 59 years.

2. 2. Elderly $=$ between 60 to 74 years.

3. 3. Old age $=$ between 75 to 90 years

4. 4 . Very old $=$ above 90 years old.$^{11}$

Aging is a cumulative change in living things, including the body, tissues, and cells, which experience a decrease in functional capacity. The decline in the elderly (elderly) is clearly stated in the Qur'an: "Allah, it is He Who created you from a weak state, then He made you after your weak condition became strong, then He made you after you were strong you returned weak and gray. And creates what He wills, and He is the All-knowing, the All-powerful." (Surah Ar-Rum: 54).12 In addition, there is the word of God: "God created you, then died you; And some of you have been brought back to the age of the weakest (senile), so that He may no longer know anything that he once knew. Verily, Allah is All-Knowing, All-Powerful (Surah An-Nahl: 70).13

In a longitudinal study of psychological aging, there are 4 (four) individual classification patterns in the aging process ${ }^{14}$ :

1. The first pattern is that elderly people achieve a relatively high level of cognitive function, although they become physically weak, but remain independent until near their death.

2. The second pattern is a group of elderly people who are the second group who only achieve a modest tendency in cognitive development, but on the other hand, along with the aging process, they need greater support and are more likely to experience a period of institutional care. Members of this group are socio-economically capable, so they are less anxious about the aging process, and tend to be more open to experience than most of their peers.

3. The third pattern, MCI, includes a group of individuals who, at an early age, experience greater cognitive decline than is normative. They indicate memory loss or possible dementia.

4. The fourth pattern includes individuals who, at an early or advanced age, were diagnosed with dementia. Regardless of the specific cause of dementia, these people have the same dramatic impairment in cognitive function. Also when followed longitudinally, at least some of these individuals show an earlier decline, perhaps starting in middle age, which is closely associated with decreased function of nerves or neurons in the brain.

Many people feel worried and afraid to face life in old age. This concern becomes a problem for the elderly who sometimes arise because of the emotional tension that increases in old age along with the changes that occur at age as the characteristics of a person who has entered old age. ${ }^{15}$ Health problems that often occur in the elderly are different from adults, which is often

\footnotetext{
${ }^{11}$ Nugroho. Gerontic \& Geriatric Nursing, edition 3. Jakarta : EGC, 2012.

${ }^{12}$ Adz-Dzikraa-Translation and Interpretation of the Qur'an. Bandung: Angkasa, 1987. Surah Ar-Rum: 54.

${ }^{13}$ Adz-Dzikraa-Translation and Interpretation of the Qur'an. Bandung: Angkasa, 1987. Surat An-Nahl: 70.

14. Warner Schaie and Sherry L. Willis K. Warner Schaie. Psychology Of Aging Eight Edition, Theoretical Perspectives for the Psychology of Aging in a Lifespan Context K. Elsevier Inc. 2016.

15 Ridlawati Romadlani et al. "The Relationship between Family Support and Elderly Independence with Elderly Self-Concept in Bambankerep Village, Ngaliyan District, Semarang City." Community Nursing Volume 1, No. 1 (May 2013): 19.
} 
referred to as the geriatric syndrome, which is a collection of symptoms regarding health that are often complained of by the elderly and or their families, namely ${ }^{16}$ :

1. Immobility (less moving)

2. Instability (easy to fall)

3. Incontinence

4. Intellectual impairment (intellectual impairment/dementia)

5. Infection (infection)

6. Impairment of hearing, vision and smell (impaired hearing, vision and smell)

7. Isolation (Depression)

8. Inanition (malnutrition)

9. Impecunity (poverty)

10. Iatrogenic (suffering from drug-induced disease)

11. Insomnia (difficulty sleeping)

12. Immuno-deficiency (decreased immune system)

13. Impotence (sexual disorders)

14. Impaction (difficult bowel movements)

Problems in the elderly are seen as a result of the changes they experience that accompany the aging process and reactions to these changes also vary depending on the personality of the individual concerned. The increased emotional tendency makes them experience these changes as a problem, resulting in the emergence of mental health disorders which include anxiety, fear in dealing with it. In general, there are several forms of problems that exist in the elderly, including ${ }^{17}$ :

a. The problem of work, with its slowness, elderly people feel less appreciated and not needed at work.

b. Interest problems, elderly people feel apathetic and bored more quickly in trying new things.

c. Isolation and loneliness, with the decline in intellectual qualities, make it difficult for older people to adjust to the new ways of thinking and styles of the younger generation, and vice versa. Including the estrangement of family ties and the family's indifference to the elderly, they are forced to seclude themselves in a nursing home.

d. Disinhibition, the older a person gets, the less capable they are in controlling their feelings and less able to restrain themselves in doing so, so that small things that shouldn't be a problem, but for them can evoke emotional outbursts and even outbursts of anger.

e. Mood changes, due to physiological changes in the brain and nervous system that occur in the elderly are one of the causes of mood swings and changes in several aspects of behavior.

f. The role of faith, namely the fear of seeing the last day, because old age is indeed a time when religious awareness must be increased. But not all of them feel at ease and have psychic readiness.

\section{Methods}

The design of this study is a literature review research. Research data was obtained through literature study and hermeneutics. Operationally, the researchers conducted a literature review that was sourced from books and scientific articles. Researchers searched for scientific articles relevant to the research topic through Google Scholar with the keywords "family support", "psychological health of the elderly". Scientific articles and books that are relevant to the topic are then analyzed using hermeneutics. Hermeneutics is used to interpret various relevant literature sources to obtain a proper understanding of the existing literature. The use of hermeneutics as a

\footnotetext{
16 “Kementerian Kesehatan," Masalah Kesehatan Pada Lansia, http://yankes.kemkes.go.id/read-masalahkesehatan-pada-lansia-4884.html

${ }^{17}$ McGhie, A. Application of Psychology in Nursing. Ika Pattinasarany Translation. Yogyakarta: Andi Offset, 1996.
} 
research design interprets the literature more critical and reflective. Interpretation becomes more relevant to the phenomenon and the reduction process becomes more complete. ${ }^{18}$

\section{Results and Discussion}

Based on research conducted by Meka Yusselda and Ice Yulia Wardani, published in 2016 with the title "Impact of Family Support on Quality of Life for the Elderly", concluded that there is a significant relationship between family support (emotional support, instrumental support, and appreciation) with the respondent's quality of life. Meanwhile, there was no significant relationship between family information support and the quality of life of the elderly 19 . Meanwhile, the research conducted by Vitaria Wahyu Astuti was published in 2010 with the title "The Relationship between Family Support and Depression Levels in Elderly At Posyandu Sejahtera GBI Setia Bakti Kediri". The results showed that the majority of family support provided to the elderly at the Prosperous Posyandu GBI Setia Bakti Kediri was good family support of 56 respondents (91.8\%), the level of depression in the elderly at the Posyandu Sejahtera GBI Setia Bakti Kediri was the mildest depression of several 51 respondents $(83.60 \%)$, there is a relationship between family support and the level of depression in the elderly at the Sejahtera Posyandu GBI Setia Bakti Kediri with a value of $=0.000 .{ }^{20}$

The support received by the elderly varies in both the source and the type of support. Sources of support for the elderly do not only come from the family but can come from the orphanage and other people such as students or university students, government officials, and community organizations that care for the elderly in the orphanage. The meaning of family support for the elderly is considered a positive thing that can provide inner pleasure. This raises the expectation of the elderly while in the nursing home for family support, including maintaining relationships while in the orphanage.

Increasing family support by giving attention and togetherness to parents is something that is needed for the psychological health of the elderly. In old age, it is also possible for unavoidable changes to occur, this causes a setback, one of which is easy fatigue, reduced vision, sluggish movement due to failure of balance defense against physiological stress conditions, including memory and sensitivity to things. certain in life. Based on the results of a survey on negative emotions and anxiety, the results obtained were $75 \%$ and $69 \%$ of negative emotions and anxiety experienced by the elderly. ${ }^{21}$

Family support is an attitude, an act of family acceptance of family members, in the form of informational support, assessment support, instrumental support, and emotional support. ${ }^{22}$ So family support is a form of interpersonal relationship that includes attitudes, actions, and acceptance of family members, so that family members feel that someone is paying attention. People who are in a supportive social environment generally do better than their peers without this advantage, because family support is thought to reduce or buffer the effects of an individual's mental health. In addition, it can provide great hope for parents to continue to instill many positive things and reduce the negative possibilities experienced by parents. ${ }^{23}$

\footnotetext{
${ }^{18}$ Larkin, M., Eatough, V. and Osborn, M. Interpretative Phenomenological Analysis and Embodied, Active, Situated Cognition Theory \& Psychology, 2011.

${ }^{19}$ Meka Yusseida and Ice Yulia. The Impact of Family Support on the Quality of Life for the Elderly. Jakarta: UI Press, 2016.

${ }^{20}$ Vitria Wahyu S. The Relationship between Family Support and Depression Levels in the Elderly at the Prosperous Posyandu GBI Setia Bakti Kediri. Kediri: STIKES RS. Baptist, 2010.

${ }^{21}$ Mierrina, and Pradana Charis Rizki. "Psychological Health Of Elderly People In The Covid-19 Pandemic". International Conference on Sustainable Health Promotion 2, no. 1 (October 6, 2021): 44-47. http://proceedings.uinsby.ac.id/index.php/ICOSHPRO/article/view/474.

${ }^{22}$ Friedman, M. Textbook of Family Nursing: Research, Theory, and Practice. Jakarta: EGC, 2011.

${ }^{23}$ Ayusi Ikasi. "The Relationship of Family Support to Loneliness (Loneliness) in the Elderly" JOM PSIK Vol. 1, No. 2 (October 2014): 2.
} 
The family factor is such an important factor for elderly people in building the meaning of life, positive emotions, spiritual experiences and rituals. When the family factor in a person's life provides positive things related to these four dimensions, of course, it is relatively unlikely to cause psychological problems for the elderly. In the absence of depressed conditions felt by the elderly, it has implications for the minimization of disturbances in the neurospiritual system in the brain, which means that family conditions or factors that function as a support system for elderly people, allow them to be more minimal in experiencing problems. psychological. On the other hand, if the family factor does not function as a support system for the elderly, it is possible for them to feel depressed which has implications for the emergence of disorders in the neurospiritual system, so that it will affect the increase in psychological problems felt by the elderly.

In addition, experiences related to the meaning of the life of the elderly are accumulated starting from childhood, gradually continuing to adolescence, adulthood to old age, which is the result of interactions between elderly people and their families throughout their lives. This is closely related to their meaning of the values of life that they have lived throughout their vulnerable lives, as well as their self-acceptance related to their emotional reactions to the changes or physical setbacks they experience. This shows how important family bonds and support are for the elderly, which in turn will contribute to the meaning of the life of the elderly themselves.

Acceptance and support by this family has a great influence on the physical and mental health conditions of the elderly. Feelings of loneliness and isolation decrease, may not even appear on the surface, when older people have involvement and activities with family. They feel that they are still "meaningful" and not "abandoned" by their family members. The involvement of the elderly in the family, in which there is support and acceptance by the family, allows the elderly to more easily adapt to changes in themselves, including the decline in various physical and mental functions.

As for one form of support given to the elderly, namely attention, which is a mental process when stimuli or a series of stimuli become prominent in consciousness when other stimuli weaken. ${ }^{24}$ Attention occurs when we concentrate on one of our sense organs and put aside inputs through the other senses. Attention can be defined as the process of concentrating the phases or elements of experience and neglecting others. Attention is given in 4 ways, including giving something or a favorite item, being a good listener, being a confidant, and inviting jokes (laughter). The four ways of giving attention have benefits, namely, parents feel happy, feel loved, feel at ease. In addition, the expected impact is that elderly people become less stressed, prevent a decrease in appetite due to many thoughts, and increase enthusiasm.

From the description above, that giving attention as a form of family support is not only limited to fulfilling physical needs but also includes emotional and affection needs. Sincere and sincere acceptance from the family of the existence of the elderly, makes the elderly feel "meaningful" and "appreciated".

In addition, another form of support given to the elderly is togetherness or intimacy, which is defined as a positive emotional bond that includes mutual understanding and support. 25 Familiarity occurs in a well-established friendship, including people who like each other, enjoy each other's presence, have common interests and activities, help and understand each other, trust each other, create a sense of comfort, and provide each other with emotional support. ${ }^{26}$ There are 4 ways given, namely: taking a walk with family members, gathering with friends, accompanying all day, and respecting each other. The benefits of providing the above are that there is an increasingly close family relationship, trusted by elderly parents to be asked for any help, not awkward in expressing any opinion. The expected impact on elderly parents is that

\footnotetext{
${ }^{24}$ Jalaludin Rahmat. Communication Psychology. Bandung:Rosda Karya Youth, 2000.

${ }^{25}$ Smith, Eliot R dan Diane M. Mackie. Social Psychology 2nd Edition. Philadelpia: Psychology Press, 2000.

${ }^{26}$ Argyle H. dan Henderson K. "Friendship and Social Competence Start". Developmental Psychology 36 (3) (1997): 326-33.
} 
parents are not introverted, not easily angry, not easily depressed, and still have positive thoughts so that their psychological health can be maintained and improve their psychological well-being. ${ }^{27}$

\section{E. Conclusion}

Examining the results of this study, it can be concluded that family support has a major influence on the psychological health of the elderly. Along with the aging process and the decline in cell function, elderly people experience physical and psychological health problems. but this impact can be minimized with family support. Family support is given in the form of interpersonal relationships which include attitudes, actions and acceptance of family members, so that family members feel that someone is paying attention. Family support can provide great hope for elderly people to continue to instill many positive things and reduce the negative possibilities experienced by them.

Ways to provide support to the elderly can be: taking family members for walks, hanging out with friends, being with them throughout the day, and respecting one another. The benefits of providing the above are that there is an increasingly close family relationship, trusted by elderly parents, to be asked for any help, not awkward in expressing any opinion. The expected impact on parents is that parents are not closed, not easily angry, not easily depressed, and still have positive thoughts so that they can improve their standard of living.

Thus, family support that is given sincerely and sincerely by family members to the elderly will build positive emotions in them, which will directly affect their psychological health, which in the end also has implications for their physical health. Even though elderly people are experiencing unhealthy physical conditions, with family support, it is possible for the elderly to maintain positive emotional conditions. Care and support for the elderly is very much needed to provide a more positive life expectancy for the elderly.

\section{References}

Adz-Dzikraa. Translation and Interpretation of the Qur'an. Bandung: Angkasa, 1987.

Agnesia Priska L Kelen et al. "The Duties of Families in Health Care with Elderly Coping Mechanisms." Scientific Health Sciences Vol 4, No 1 (2016).

Argyle H. dan Henderson K. "Friendship and Social Competence Start". Developmental Psychology 36, No 3 (1997): 326-33.

Ayu Nurmalasari. Forms of Family Support for Elderly Attitudes in Maintaining Mental Health. Jember: UNEJ, 2010.

Ayusi Ikasi. "The Relationship of Family Support to Loneliness (Loneliness) in the Elderly" JOM PSIK Vol. 1 No. 2 (October 2014): 2.

CNN Indonesia Team. "Challenges Facing Elderly in Indonesia". Last modified September 24, 2019.

https://www.cnnindonesia.com/gaya-hidup/20190709091033-255-410379/tantangan-yangdihadapi-lansia-di indonesia

Friedman, M. Textbook of Family Nursing: Research, Theory, and Practice. Jakarta: EGC, 2011.

Liberty Home Care. "Why a Family Support System is Important for The Elderly". https://libertyhomecare.com/why-a-family-support-system-is-important-for-the-elderly/

Kementerian Kesehatan. "Masalah Kesehatan Pada Lansia”. http://yankes.kemkes.go.id/readmasalah-kesehatan-pada-lansia-4884.html

\footnotetext{
${ }^{27}$ Ayu Nurmalasari. Forms of Family Support for Elderly Attitudes in Maintaining Mental Health. Jember: UNEJ, 2010.
} 
Kementerian Kesehatan. "Indonesia Enters the Period of Aging Population". Last modified July 04, 2019. https://www.kemkes.go.id/article/view/19070500004/indonesia-entered-periodaging-population.html, published On: Thursday, 04 July 2019

Jalaludin Rahmat. Communication Psychology. Bandung:Rosda Karya Youth, 2000.

Johana E. Prawitasari. "Socio-Psychological Aspects of the Elderly in Indonesia". Bulletin of Psychology Volume 1, No: 1 (1994): 27-34.

Kementerian Kesehatan. "Keep the Elderly Healthy During the Covid-19 Pandemic". Last modified June 25, 2021. https://promkes.kemkes.go.id/tetap-sehatkan-lansia-di-masa-pandemicovid-19

Keren Cohen, Louck and Yael Aviad, Wilchek. "Family Support, and Social Engagement of the Elderly Residing in the Community and in Institutional Settings". Isr J Psychiatry Suicidal Tendencies, Meaning in Life Vol. 57, No 1 (2020).

Larkin, M., Eatough, V. and Osborn, M. "Interpretative Phenomenological Analysis and Embodied, Active, Situated Cognition" Theory \& Psychology (2011): 1-20.

Man Hung et al. "The Relationship Between Family Support; Pain and Depression in Elderly With Arthritis" Psychology, Health \& Medicine Volume 22 (2017).

McGhie, A. Application of Psychology in Nursing. Ika Pattinasarany Translation. Yogyakarta: Andi Offset, 1996.

Meka, Yusseida and Ice, Yulia. "The Impact of Family Support on the Quality of Life for the Elderly". Jakarta: UI Press, 2016.

Mierrina, and Pradana, Charis Rizki. "Psychological Health of Elderly People In The Covid-19 Pandemic". International Conference on Sustainable Health Promotion 2, no. 1 (October 6, 2021): 44-47. http://proceedings.uinsby.ac.id/index.php/ICOSHPRO/article/view/474.

Nugroho. Gerontic \& Geriatric Nursing, edition 3. Jakarta: EGC, 2012. Psychology of Aging. American Psychological Association.

Ridlawati, Romadlani et al. "The Relationship between Family Support and Elderly Independence with Elderly Self-Concept in Bambankerep Village, Ngaliyan District, Semarang City" Community Nursing Volume 1, No. 1 (May 2013): 19.

Smith, Eliot R dan Diane M. Mackie. Social Psychology 2nd Edition. Philadelpia: Psychology Press, 2000.

Vitria Wahyu S. The Relationship between Family Support and Depression Levels in the Elderly at the Prosperous Posyandu GBI Setia Bakti Kediri. Kediri: STIKES RS. Baptist, 2010.

Warner, Schaie and Sherry, L. Willis K. Warner Schaie. Psychology of Aging Eight Edition. Theoretical Perspectives for the Psychology of Aging in a Lifespan Context. Elsevier Inc., 2016. 